\title{
Novel Synthesis of Phlorin Derivatives and Their Anion Binding Properties
}

\author{
Seong-Jin Hong, Jac-Won Ka, Dong-Hoon Won, and Chang-Hee Lec * \\ Institute of Basic Science and Department of (hemistr), Kangwon National (niversity; (hwm-Chon 200-701, Korea \\ Recened February,+ 2003
}

Key Words : Phlorins, Oxophlorin, Calix[4]phyrin, Chromogenic sensor

Phlorins are one of the intermediate structures between calix[4]pyrrole and porphyrin. Phlorins bearing one $s p^{3}$ hybridized meso-carbon have been known to be unstable and only a few have been characterized so far.' Compounds bearing meso-hydrogens are known to be especially unstable. Due to air sensitive nature of the compound, bridging unit between $N(21)$ and $N(22)$ or $N$-substituents were introduced in some cases for the stabilization of the compounds. ${ }^{2}$ We recently reported the synthesis of phlorin 2 via oxidant-mediated coupling of pentapyrrotetramethane $\mathbf{I}$ which was easily converted to the corresponding porphyrin under strongly acidic conditions."
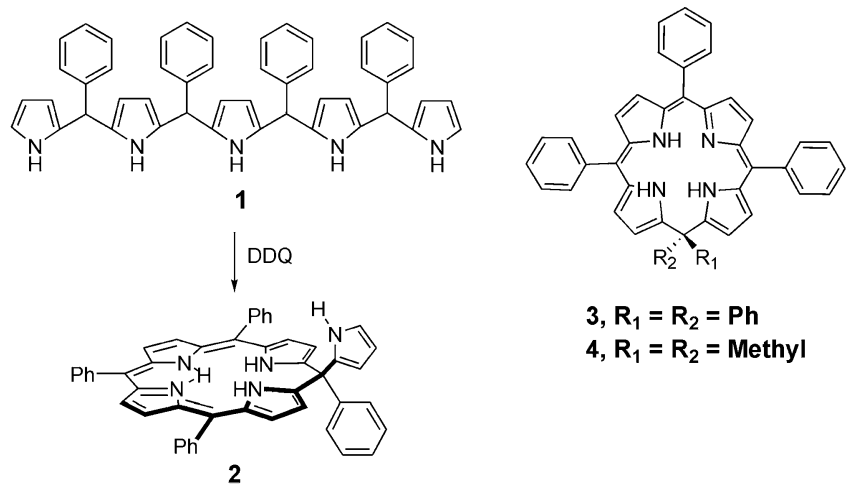

3, $R_{1}=R_{2}=P h$ $4, R_{1}=R_{2}=$ Methyl

The fully meso-oxidized macrocycles, porphyrins are cation coordinating while the reduced porphyrin analogues has been recognized as anion receptors. ${ }^{4}$ Especially calix[4]pyrroles have been extensively studied as easily accessible anion receptors. But, anion binding chemistry for stable phlorin analogues such as 2,3 and $\mathbf{4}$ has not been studied well so far and thus here we report the novel ' $2+2$ ' type synthesis of stable phlorin derivatives and their anion binding behaviour in organic solvents.

Sessler $e t a l$. reported an attempted synthesis of compound 4 by acid catalyzed condensation of tetrapyrrotrimethane

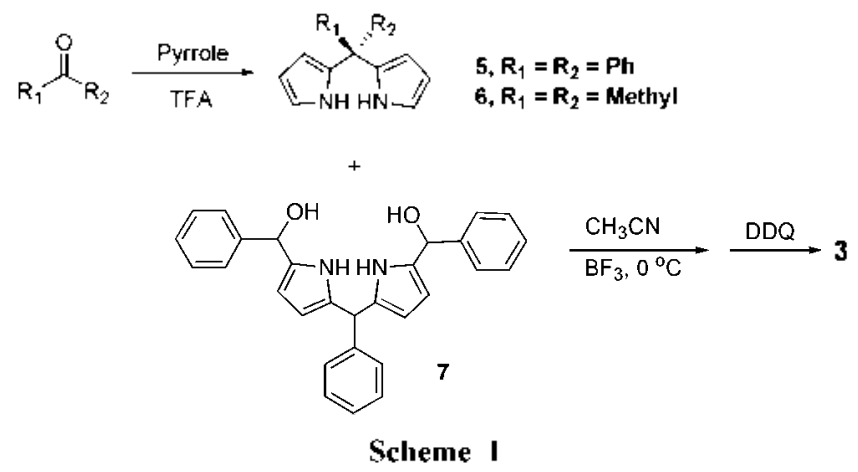

(linear tetrapyrrolic oligomer) with acetone, resulting unexpected isolation of meso-hydroxylated calixphyrin." Our approaches for the synthesis of compound 3 and 4 are shown in Scheme 1. Dipyrromethanes 5 and $\mathbf{6}$ were easily synthesized by acid-catalyzed condensation of corresponding ketone with pyrrole. lyrrole was used as solvent as well as a reactant in these reactions. The product was easily isolated by vacuum distillation. ${ }^{\text {t }}$

The condensation of acetone with pyrrole afforded mesodimethyldipyrromethane 6 in $60 \%$ yield while condensation of the benzophenone with pyrrole gave lower (12\%) yield of 5. Then diol 7 synthesized as previously reported procedure ${ }^{7}$ was used as southern half of the expected product. Treatment of 7 with 5 in acetonitrile in the presence of $B F_{3}$, followed by DDQ oxidation and column chromatography of the resulting mixture afforded 3 in $2 \%$ yield. Similar condensation of 7 with 6 under the same condition did not afford the desired product but polymeric material and small amount of ' $\mathrm{T}$ 'P. Mixed condensation of meso-dimethyldipyrromethane $\mathbf{6}$, benzaldehyde and meso-phenyldipyrromethane $\mathbf{8}$, followed by DDQ oxidation afforded mixture of products $9, \mathbf{1 0}$, and 11 in $9 \%, 1 \%$ and $4 \%$ respectively (Scheme 2 ).

The formation of 9 and 11 is easily predicted and the reaction did not afford the cross-condensation product (i.e.
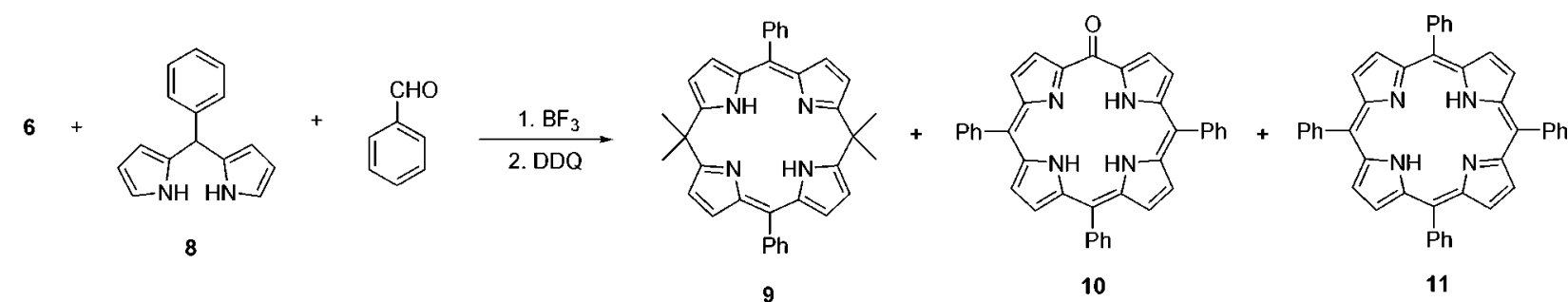

Scheme 2 


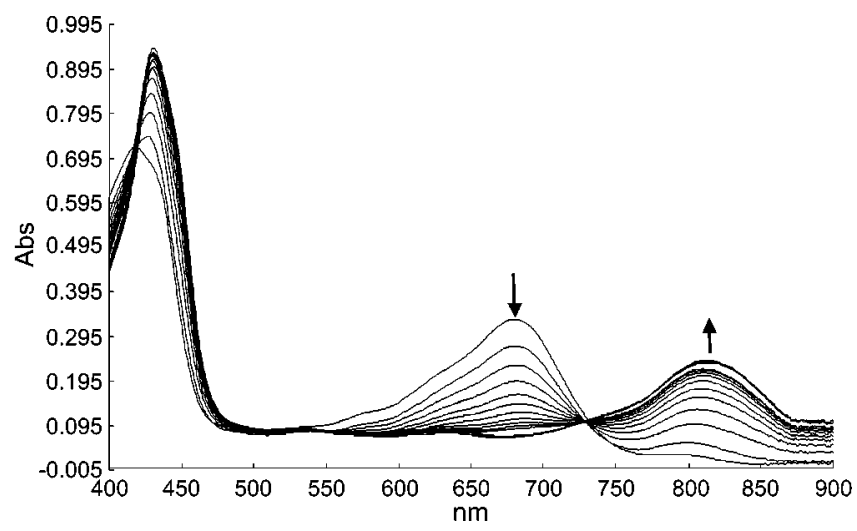

Figure 1. UV-Vis, Spectral titration with telrabulylammonium tluoride $(\mathrm{TB} \Lambda \mathrm{F}) .[2]=2.65 \times 10^{-5} \mathrm{M}$ in $\mathrm{CHC} \mathrm{J}_{3}$ at $25{ }^{\circ} \mathrm{C}$. Fach spectrum was taken after adding 0.1 equiv. of guest.

condensation of 6.8 and two molecules of benzaldehyde). The formation of oxophlorin $\mathbf{1 0}$ is rather unusual on the other hand and considered to be formed by elimination of phenyl group from $\mathbf{8}$ followed by condensation with benzaldehyde and consecutive oxidation of meso-position. The compound 9 shows a single pyrrolic $\mathrm{N}-\mathrm{H}$ resonance at $\mathrm{l}+\mathrm{l} 10$ $\mathrm{ppm}$ which indicates the existence of strong intra-molecular lyddrogen bonding. The proton NMR spectrum of $\mathbf{1 0}$ reveals the presence of single $\mathrm{N}-\mathrm{H}$ resonance at $-1.68 \mathrm{ppm}$. UV-vis spectrum of 10 shows typical porphyrin-like absorption (Soret at $409 \mathrm{~nm}$. Q band at $505 \mathrm{~nm} .539 \mathrm{~lm} .569 \mathrm{~nm}$ and $619 \mathrm{~nm})$ and IR spectnum shows a typical carbonylstretching band of oxopllorin at $1560 \mathrm{~cm}^{-1}$ indicating the compound exist as keto-form.

The ability of the meso-py rrylphlorin 2 in binding with fluoride anion was investigated using UV-ris spectroscopy. As shown in Figure 1. the solution of $\mathbf{2}$ undergoes dramatic color changes by binding with fluoride anion. In the absence of anions. 2 is characterized by deep green colour. Upon gradual addition of $\mathrm{F}^{-}$. the colour becomes yellowish. This colour change exclusively occurs with $\mathrm{F}^{-}$and no detectable change in colour is observed with other halogen anions such as $\mathrm{Cl}^{-}$. $\mathrm{Br}^{-}$and $\mathrm{l}^{-}$. This anion-induced red-shift show nakedeve detectable color change. Titration of $\mathbf{2}$ with fluoride anion gave $1 / 2$ binding isotherm and the Jop-plot shown in Figure 2 confirms the binding ratio. The calculated association constants for fluoride weres $\mathrm{K}_{1}=3.0 \times 10^{4} \mathrm{M}^{-1}$ and $\mathrm{K}_{2}=1.2$ $\times 10^{5} \mathrm{M}^{-1}$.

The binding stoichiometry of 2 with fluoride anion may indicate that one host molecule bind with two fluoride anions. Similar titration behaviour was observed with compound 3 with fluoride anion. The obtained binding constant was almost identical within the experimental error with those of compound 2 . These obserations indicate that the existence of additional hydrogen-bonding donor do not enhance the binding constant as predicted. Degree of distortion of the molecule from planarity in 3 must be somew hat larger than that of 2 . Thus the pyrrolic $\mathrm{NH}$ in the core may not be available for hydrogen bonding.

ln summary: several meso-substituted phlorins was synthe-

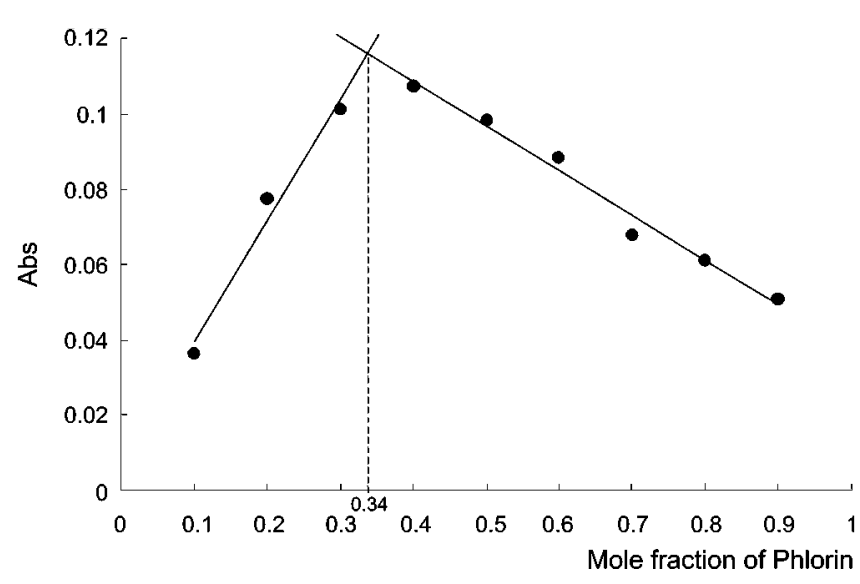

Figure 2, Job plot for 2 with l'BAF: [2] $=4.2 \times 10^{5} \mathrm{M}$ in CIKCl at $25^{\circ \mathrm{C}} \mathrm{C}$

sized and anion-binding properties were studied. The results indicate that phlorins could be excellent host for fluoride anion. It is also possible to conceive the use of phlorin in colorimetric sensing systems due to the dramatic color changes by forming host-guest complexes. Synthesis of various analogues and their anion binding activities are under investigation.

\section{Experimental Section}

'H NMR spectra $(400 \mathrm{MHz}$. Bruker DPX-400) were recorded in $\mathrm{CDCl}_{3}$ with TMS as the internal standard. $\mathrm{FAB}$ mass spectra were obtained on AUTO SPEC M-363 highresolution mass spectrometer. UV-vis spectra were recorded on Cary-100 spectrometer. Column chromatography was performed on silica (Merck. 230-400 mesh). Pyrrole was distilled at atmospheric pressure from $\mathrm{CaH}_{\Sigma}$. All other reagents were obtained from Aldrich and used as received unless noted otherwise.

$5,5,15,15$-Tetramethyl-10.20-diphenylporphodimethene (9), 5-0x0-10,15,20-tri-phenylphlorin (10) and 5,10,15,20tetraphenylporphyrin (11). Compound 6 (302 mg. 1.7 mmol). 8 (386 mg. $1.7 \mathrm{mmol}) . \mathrm{NH}_{\lrcorner} \mathrm{Cl}(937 \mathrm{mg} .17 .5 \mathrm{mmol})$ and benzaldehyde ( $352 \mu \mathrm{L}, 3.46 \mathrm{mmol}$ ) were dissolved in acetonitrile $(17+\mathrm{mL})$. The mixture was stirred for $5 \mathrm{~min}$ then added $\mathrm{BF}_{3}, \mathrm{OEt}_{2}(4+\mu \mathrm{L} .0 .347 \mathrm{mmol})$. The whole mixture was stirred for $30 \mathrm{~min}$ at room temperature then added trietlyy lamine ( $2 \mathrm{~mL}$ ) in order to quench the reaction. The mixture was combined with DDQ $(0.18 \mathrm{~g} .5 .20 \mathrm{mmol})$ and stirred for $\mathrm{l} h$ at room temperature. The whole mixture was extracted with methylene chloride $(20 \mathrm{~mL} \times 3)$ after adding $30 \mathrm{~mL}$ of water. The organic layer was dired $\left(\mathrm{Na}_{2} \mathrm{SO}_{\dashv}\right)$ and the solvent was removed in vacto. The resulting black solid was separated by column chromatography on silica $\left(\mathrm{CH}_{2} \mathrm{Cl}_{2}\right)$ to remove 5-oxophlorin 10. The second fraction containing 9 and 11 were separated by additional columu chromatography on silica $\left(\mathrm{CH}_{2} \mathrm{Cl}_{2} / \mathrm{Hexanes}=1 / 2\right)$. Each compound was recrystallized from methanol to afford analytically pure products. Yield for (9) $40 \mathrm{mg}(9 \%)$ : ' $\mathrm{H}$ NMR $\left(\mathrm{CDCl}_{\mathrm{s}}\right) \delta 1.95$ (s. $12 \mathrm{H} . \mathrm{CH}_{\mathrm{s}}$ ) $6.2+$ (d. $J=+.2 \mathrm{~Hz} .2 \mathrm{H}$. 
py rrole-H), 6.33 (d. $J=4.2 \mathrm{~Hz} .2 \mathrm{H}$. py rrole-H), 7.38-7.4. (in. $10 \mathrm{H}$. Ar-H). 14.2 (br s $2 \mathrm{H}, \mathrm{NH}$ ); FAB-MS Calcd for $\mathrm{C}_{36} \mathrm{H}_{30} \mathrm{~N}_{1}$ 520.26. Found $521.22\left(\mathrm{MH}^{\prime}\right)$. Yield for (11) 19 mg. $(4 \%)$ : ' $\mathrm{H}$ NMR $\left(\mathrm{CDCl}_{3}\right) \delta-2.78$ (s. $12 \mathrm{H}$. NH). 7.737.78 (m. 12H, Ar-H). 8.21-8.23 (m. 8H, Ar-H). 8.84 (s. $8 \mathrm{H}$. py rrole-H). For (10) Yield $6 \mathrm{mg}(1 \%)$ : ${ }^{1} \mathrm{H}$ NMR $\left(\mathrm{CDCl}_{3}\right) \delta$ -1.68 (s. 2H. NH). 7.71-7.79 (m, 10H. Ar-H). 8.13-8.16 (m. $5 \mathrm{H}, \mathrm{Ar}-\mathrm{H}), 8.6+(\mathrm{d} . J=8.6 \mathrm{~Hz}, 2 \mathrm{H}$. pyrrole-H). $8.71(\mathrm{~d} . J=$ $8.6 \mathrm{~Hz} .2 \mathrm{H}$. py rrole-H), $8.9+$ (d. $J=8.8 \mathrm{~Hz} .2 \mathrm{H}$. py rrole-H). 9.12 (d. $J=8.8 \mathrm{~Hz}, 2 \mathrm{H}$, pyrrole-H): FAB-MS Calcd for $\mathrm{C}_{38} \mathrm{H}_{\Sigma 6} \mathrm{~N} .1 \mathrm{O}(5.54 .2 \mathrm{l})$. Found $(5.56 .39)(\mathrm{M}+2)$.

Acknowledgments. This work was supported by grants from the Korea Science and Engineering Foundation (KOSEF R05-2000-000-00077-0). The NMR and mass data were obtained from the central instrumental facility in Kangwon National University:

\section{References}

1. (a) Setsune. J.: Yamaji. H.: Kailo. T. Tetwohedron Leeft. 1990. 31. 5057-5060. b) Selsune. J.: Ikeda. M.: lida. T.: Kitao. I. J. im. (hem. Soc. 1988. 110.6572-6574. (b) Khoury. R. G.: Jacuinod. J.: Shacliter, A. M.: Nelson. N. Y.: Smitl. K. M. Chem. Commm. 1997,215
2. (a) Ruppert. R.: Jeandon. C.: Sgambati. A.: Callot. H. J. Chom. (ommun. (c'ambridge) 1999. 2123-2124. b) Krattinger. B.: Callot. H. đ. Tetrahedron Lett. 1996. 37. 7699-7702.

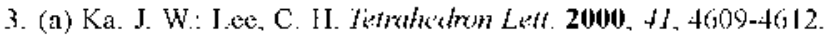

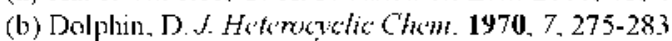

4. (a) Sessler. I. L..: Anzenbacher .Jr. P.: Jursikova. K.: Miyaji. IL.: Genge. I. W.: Tvermoes. N. A.: Allen. W. E.: Shriver. I, A. Pure of Appl (Them, 1998. 70. 2401-2408. (b) Sessler. J, L.: Zimmerman. R. S.: Bucher. C.: Kral. V.: Andrioleti. B. Pure \& Appl. Chem. 2001, 73. 1041-1057

5. Bucher, C.: Siedel. D.: Ixneh, V:: Kral. V.: Sessler. I. I. Org. Let. 2000, 2. 3103-3106

6. A typical procedure for the synthesis of 6 : lo a stined misture of pyrrole $(6.0 \mathrm{~mL} .86 .1 \mathrm{mmol})$ and acetone (1.3 $\mathrm{mL} .7 .21 \mathrm{mmol})$ was added trifluoroacetic acid (0.13 mL. $1.72 \mathrm{mmol})$. The mixture was stirred for 5 min at room temperature and the mixture was combined with aqueous $\mathrm{NaOH}(0.1 \mathrm{~N}$. $50 \mathrm{mI}$.). The mixture was extracted with methylene chloride and solient and prorole was removed in vacuo, Vacuum distillation using Kugelrohr $\left(120^{\circ} \mathrm{C}\right.$. $0.05 \mathrm{mmHg})$ gave pure product as white sold. Yield $1.8 \mathrm{gr}\left(60^{\mathrm{u}} 0\right)$ : 'H NMR (CDCl $\left.{ }_{3}\right) \delta 1.63$ (s. $6 \mathrm{H}$. methyl). 6.08 (m. 2H. pyrolicII), 6.13 (m. 2H. prrolic-II), 6.61 (m. 2I I, pyrrolic-II). 7.70 (brs, 2II, NII)

7. (a) I.ce. C. II.: I.i, F.: Iwamoto. K.: Dadok, J.; Bothemerby: $\Lambda$.: Lindsey. J. S. Tetrohedron 1995. 51. 11645-11672. (b) Cho. W. S.: Kim. H. J.: Littler. B. Ј.: Miller. M. A.: Lee. C. H.: Lindsey. . . S. J. Org. (hom 1999. 61.7890-7901.

8. Clezs: P. S.: I icpa. A. J. Alust J. Chem. 1970. 23. 2461-2476 